\title{
The Russian iambic tetrameter: The problem of description (Prolegomena to a new paradigm)
}

\section{Sergei Liapin*}

\begin{abstract}
From the very beginning of systematic investigation of the Russian iambic tetrameter (1910s-1940s), the proportion of stresses on the first and second ictus of the line was chosen as its main rhythmic characteristic. Meanwhile, attributing an aesthetic value to this characteristic is wrong: it is largely dependent on the changing speech norm in the late 18th an early 19th century. The general trend in the evolution of the Russian iambic tetrameter from the mid 18th to the mid 20th century can be described as an increase in the degree of rhythmic diversity of this metre. Every rhythmic form of the iambic tetrameter approximates as close as possible to the frequency predetermined by the general norms of the Russian literary language. Both processes (changes in the speech norm and the growth of rhythmic diversity of the metre under consideration) are illustrated by statistical data.
\end{abstract}

Keywords: Russian iambic tetrameter, metre, rhythm, speech norms, evolution

A poetic text written in a particular metre meets certain metric standards. There are, however, other factors which affect the structure of the text and are also involved in the creation of the verse form. To study these factors, we need to develop adequate parameters of description, which would disambiguate the definitions of the structural features of poetic speech.

From the very beginning of systematic investigation of the Russian iambic tetrameter (1910s-1940s), the proportion of stresses on the first and second ictus of the line was chosen as its main rhythmic characteristic (Belyi 1910: 261-264; Taranovsky 1953: 68-70). Meanwhile, it has become clear in recent years that attributing an aesthetic value to this characteristic is based on a misunderstanding, ${ }^{1}$ and therefore observations and conclusions based this

* Author’s address: Sergei Liapin, Pulkovskaia str. 19-50, St. Petersburg 196158, Russia, email: liapin@mail.ru.

1 See Červenka 1973; Kholshevnikov 1973; Petrova 2010; Liapin, Pilshchikov 2012: 429; Levashov 2015 and Liapin 2015 (both chronicled in Polilova, Levashov 2015: 382, 383); Liapin, Florinskaja (Liapina), forthcoming. 
premise require proper verification. The primary task, however, is to reveal the reason why this error occurred.

Let us start with an example.

A Russian four-foot iambic line easily skips ictic stresses. Among the eight rhythmic forms of the iambic tetrameter, as they were described by Shengeli (1923: 139-141), Form III - the one with the skipped stress on the second ictus - is of special interest:

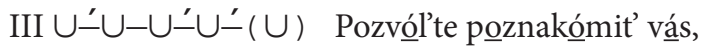
Pochúvistvovat $t^{\prime}$ dobrá prijátstvo. ${ }^{2}$

Until recently it was believed that this form was aesthetically appealing for the Russian poets of the 18th century, whereas Russian 19th-century poets tended to avoid it. My observations on the speech structure of Gavriil Derzhavin's odes (1779-1791) demonstrated the fallacy of this dichotomy (Liapin 1997a, 1997b).

However, there is an important question that has not been clarified until now: what caused a relatively low frequency of Form III in the majority the early 19th century poets? ${ }^{3}$ One of the suggested explanations is that the accentual sequence of such a line was allegedly perceived as inappropriate to the lyric and lyrico-epic verse of the 19th century, whereas an organic link of such a line with the style of 18 th century poetry, especially the solemn ode, was presumed (Kholshevnikov 1981: 241-242; Gasparov 1984: 135). This thesis can be verified or disproved in different ways. One possible way is a direct appeal to the reader's experience. I quote the full text of Fedor Tumansky's short poem "Ptichka" (“The little bird"):
III Vcherá ja rastvorị́l temnịtsu
IV Vozdúshnoj plénnitsỵ moéj:
III Ja róshcham vozvratíl pevítsu,
II Ja vozvratíl svobódu éj.
IV Onà ischézla, ütopája
III V siján’i golubógo dnjá,

2 In this and other examples, ictuses are underlined. Other Shengelian forms are as follows:

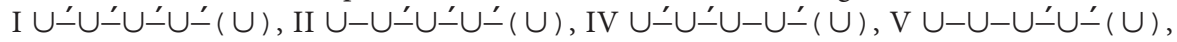
VI $\cup-\cup \dot{U} \cup-\cup \dot{㇒}(\cup)$, VII $\cup \dot{U} \cup-\cup-\cup \dot{㇒}(\cup)$, and VIII $\cup-\cup-\cup-\cup \dot{\prime}(\cup)$. The last ictus is always stressed (exceptions are considered to violate strict versification rules). Forms $\mathrm{V}$ and VIII are extremely rare.

3 The fact that the proportion of Form III, in relation to that of other forms, decreased drastically as early as the last decade of the 18th century is usually ignored (see charts $2-7$ below). 
IV I ták zapéla, ulletája,

VI Kak bỵ molílas’ za menjá. ${ }^{4}$

This poem was composed between 1820 and 1826; it was published in 1827 . Perfect in form, it was highly appreciated by the poet's contemporaries and later critics. The intonation of "The little bird" is, one might say, antithetical to the odic intonation: instead of the oratorical verse with its hampered diction, we are dealing with the light and versatile rhythm of a lyrical miniature. At the same time, Form III is predominant here, and its proportion is 1.5-2 times higher than in Derzhavin's odes.

For comparison, we present an exemplary strophe from one of Derzhavin's odes, "Na smert' grafini Rumjantsevoj" ("On the death of Countess Rumjantseva”, 1788):
IV Vozzrí na pámjatnik sej véchnyj
VI Ty sovreménnicy tvoéj,
IV V otrạ́du góresti serdéchnoj,
III K spokójstvijụ dushí svoéj,
I Prochtịi: "Sijà grobníca skrýla
III Zatmívshego mát' lúnnyj svét;
VI Smért' dobrodételi shchadíla,
I Oná zhilá pochtí stó léet"s.

Even from the viewpoint of their formal features (a long initial word and complex syntax) the two lines with Form III in this ode are very different from their rhythmic homonyms in Tumansky's poem.

We shall return to these examples later.

Let us now make some general evaluations.

According to Kiril Taranovsky, the main characteristic of the iambic rhythm is the difference between the frequencies of accents on the second

4 'Yesterday I opened the prison / of my airy captive: / I returned the singer to the groves, / I returned freedom to the bird. / It disappeared, sinking / in the radiance of the azure day, / And began to sing, flying away, / as if it was praying for me'. All translations from Russian are ours unless otherwise noted. $-E d s$.

5 'Behold this eternal monument / of your female contemporary; / In consolation of cordial sorrow, / in easement of your soul, / Read: "This tomb hid / the mother of the one who eclipsed the moonlight; / Death spared [her] virtues, / [and] she lived for almost a hundred years"”. 
and the first foot (if the frequency of stresses on the second is lower than on the first, the value of this parameter will be expressed by a negative number).

We will now make an initial assessment of the relevance of "Taranovsky's parameter". ${ }^{6}$ To do so, we are going to analyze Aleksandr Pushkin's iambic tetrameter. We will consider Pushkin's lyric poems composed in the period of his maturity (1823-1836) and select only those poems in which there are no fewer than 12 lines and no more than 24 lines. (This restriction is necessary to ensure the adequacy of our analysis.) Chart 1 shows how Pushkin's texts are distributed over the intervals of Taranovsky's parameter.

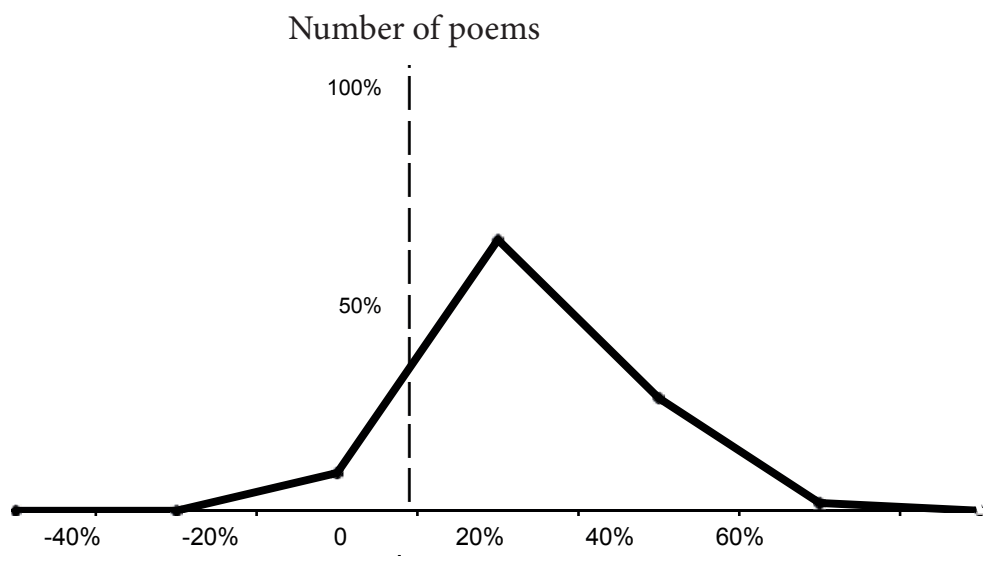

Chart 1. The iambic tetrameter of Pushkin's mature lyrics. Distribution of texts over the intervals of "Taranovsky's parameter".

The form of the graph demonstrates that the distribution of the values of this parameter is close to standard distribution. ${ }^{7}$ It follows from this that the ratio of stresses on the first two feet cannot serve as a universal feature of rhythmic peculiarity for a four-foot-iambic text. Moreover, it can be argued that the value of this parameter results from an overlap of different heterogeneous influences. This conclusion can be drawn even if we base our observations on the same amount of material as was used by Taranovsky. The latter statement is confirmed by various facts. Some of them were noticed by Taranovsky, but, as we shall see, he could not provide all of them with adequate interpretations.

6 The problem of the relevance of this parameter has not been posed before.

7 Compare an example of a non-random distribution determined by the poet's intention in Liapin 2011, where this method of analysis is explained in more detail. 
Thus, in his paper entitled "Osnovnye zadachi statisticheskogo izuchenija slavjanskogo stikha" ("The main tasks of the statistical study of Slavic verse"), where Taranovsky, in particular, juxtaposes 18th-and 19th-century Russian iambic tetrameter, we read:

\begin{abstract}
Baratynsky's lines "Svoịkh pochtítel'nykh rabọv / Porọ́ krasávitsy duráchat", "Ljubljụ roskóshnoe dovól'stvo", "I brýzzhet rádostna ja pẹ́na" would have had a different form in Derzhavin (with an inversion and a strong emphasis on the beginning of the line, so that instances of Form IV would be substituted for Form III): "Pochtítel'nykh svoịkh rabóv / Krasávitsy porój duráchat", "Roskóshnoe ljubljú dovól'stvo", "I rádostnaja brózzzhet péna”. And, conversely, Derzhavin’s line "V serébrjanoj svoèj porfíre" would have become Form IV in Baratynsky [...]: "V svoèj serébrjanoj porfíre". (Taranovsky 1966: 182) ${ }^{9}$
\end{abstract}

Only the latter statement holds true: all facts testify that Baratynsky would indeed have constructed the line in the way Taranovsky describes: ${ }^{*} V$ svoèj serébrjanoj porfíre ['in its silver mantle'] (Form IV: U-́Ú $\cup-\cup\{́ \cup$ ). But the reason is not the poet's attitude to rhythm. It is also hard to agree with Taranovsky's linguistic commentary on Derzhavin's line: "A natural, i.e. neutral word order [...] would be: [...] 'V svoèj serébrjanoj porfíre' [...]" (ibid.: 182, ftn. 6). ${ }^{10}$

What can be considered a "natural" word order? This is largely dependent on the speech norm. But the speech norm is subject to change. Let us consider our case more closely. In Derzhavin's time, in the phrasal type under consideration the pronoun tended to occupy the closest position to the noun. Baratynsky composed his poems in the period of the transition to the new norm, when a different word order became preferable. In the prose of the 1760s-1780s and early 1790s, the phrasal construction qualified as "natural, i.e. neutral" by Taranovsky, that is \{(preposition) + pronoun + adjective + noun $\}$ (svoe dobroe imja 'his/her/their good reputation', (u) svoikh bednykh sosedej '(from/of) his/her/their poor neighbours' etc.) is found in about one third of all cases, whereas more than $60 \%$ of such phrases belong to the " $v$ serebrjanoj svoej porfire" type: $\{$ (preposition) + adjective + pronoun + noun $\}$. Consider the following examples of $\{$ (preposition $)+$ adjective + a form of the possessive

8 Evgeny Baratynsky (1800-1844), a poet of the so-called "Pushkin Pleiad".

9 Metrical markup added.

10 In Derzhavin's "original" version of this line the possessive pronoun svoej ('its') follows the adjective serebrjanoj ('silver'), while in Baratynsky's hypothetical line the possessive pronoun follows the adjective. 
pronoun svoj + noun $\}$ which are taken from the prose works of 18th-century authors:

...bezumnuju svoju revnost'...,

...dlja malejshej svoej vygody... (Fonvizin);

...v predrozhdestvennom svoem sostojanii...,

...vsledstvie telesnogo svoego slozhenija... (Radishchev);

...s vernym svoim drugom...,

...kolkimi svoimi per'jami... (Novikov);

...bespreryvnogo svoego sna...,

...edinoju svoeju gordostiju... (Krylov);

...v ljutykh svoikh bedstvijakh...,

...v sobstvennoe svoe plat'je... (Karamzin);

and so forth. ${ }^{11}$

The new norm was definitively established in the work of Baratynsky and Lev Tolstoy. In Tolstoy's "Detstvo" ("Childhood", 1852) not a single example of the "older" word order is found: he used only the \{pronoun + adjective + noun $\}$ forms:

...sidel na svoem obychnom meste...,

...nesmotrja na svoi preklonnye leta...,

...snjal svoju pojarkovuju shljapu...,

...zapirat' svoikh strashnykh sobak...

and so on.

11 A clarification is necessary here. Of course, a general speech tendency should be tested against diverse and multifarious material. The following is a list of the texts we examined. Denis Fonvizin: prose comedies Brigadir (The Brigadier, 1769) and Nedorosl' (The Minor, 1781), a satirical manuscript journal in epistolary form entitled Drug chestnykh ljudej, ili Starodum (Friend of Honest People, or Mr. Oldthinker, 1788), the treatise Torgujushchee dvorjanstvo (The Commercial Nobility, 1766, a translation of G. F. Coyer's La noblesse commerçante and J. H. G. von Justi's preface to the German edition of this book), and Fonvizin's letters from St. Petersburg and Moscow (1763-1775). Nikolai Novikov: polemic articles from Novikov's journal Truten' (The Drone, 1769), which was directed against Catherine II's journal Vsiakaia vsiachina (All Sort of Things). Ippolit Bogdanovich, letters (1767-1780). Nikolai L'vov, letters (1789-1795). Aleksandr Radishchev: the philosophical treatise "O cheloveke, o ego smertnosti i bessmertii" ("On man, his mortality and immortality", 1792-1796). Ivan Krylov: the tale "Nochi" ("Nights", 1792). Nikolai Karamzin: the tales "Bednaja Liza" ("Poor Liza”, 1792) and "Natal'ja, bojarskaja doch"' ("Natalia, the boyar's daughter", 1792). The frequencies of the two variants of such a phrase vary insignificantly, but in letters they vary more. (The latter observation, however, requires testing on a broader and more heterogeneous set of material). I am grateful to Mihhail Lotman, who gave me some very useful tips on the problem of changing speech norms. 
As we can see, all this has nothing to do with the "activity of verse rhythm" advocated by Taranovsky (1971: 425; 1980 [1971]: 26, cf. 1966: 185-186, $\mathrm{ftn}$. 10). This is why, for example, the adjective with a rare accentual structure in Derzhavin's "Vodopad" (“The waterfall”, 1791-1794) precedes the possessive pronoun svoj rather than follows it:

II Velikolépnyj svọj ty khód

I Vliváesh'v svétlyj sónm Onégi.

Derzhavin makes it "Velikkolépnyj svòj ty khód..." ['your magnificent flow'],

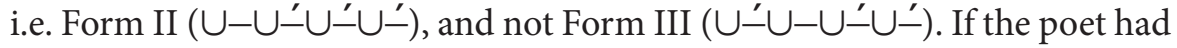
really preferred Form III to Form II, as Taranovsky thought, he could have

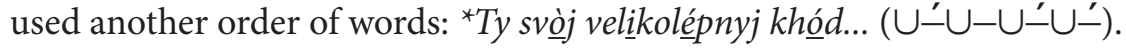

Now we can explain why Taranovsky was wrong when he alleged that Baratynsky's lines, such as "Ljubljú roskóshnoe dovól'stvo" ['I like luxurious abundance'] and "I brýzzhet rádostnaja péna" ['and sparkles the joyous foam'], "would have had a different form in Derzhavin": *Roskóshno ljubljú dovól'stvo and ${ }^{\star} I$ rádostnaja brýzzhet péna. As regards the phrases of this type $-\{$ verb + adjective + noun $\}$ - the speech norm did not change, and there is no difference between Derzhavin and Baratynsky in terms of how they used such phrases. In eleven odes composed by Derzhavin between 1779 and $1791,{ }^{12}$ there is not a single line similar to *Roskóshnoe ljubljú dovól 'stvo. In all cases, the verb begins the line, followed by an adjective and a noun that form an inseparable phrase unit: “Izbrál dostójnogo vladýku” ['(who) elected a worthy sovereign'], "Idét ognístaja zarjạ́" ['(there) goes a fiery dawn'], "Otmstít' krestóvye pokhódy” ['to revenge the holy crusades'] and so on (see Liapin 1997a and 1997b for details).

Let us now compare the two chronological periods described above, but in a different aspect: in terms of the accentual structure of the words in the line. We can reveal a certain regularity in the construction of a coherent speech fragment (eventually: verse or colon) in Baratynsky and Tolstoy: the phrase under discussion consists of a comparatively short word (a pronoun or a verb) with a stressed syllable in its right part followed by an adjective that, as a rule, is a

\footnotetext{
12 "Na smert' knjazja Meshcherskogo" ("On the death of Prince Meshchersky"), "Felitsa" ("Felice"), "Blagodarnost' Felitse" ("Gratitude to Felice"), "Reshemyslu" ("To Reshemysl”), "Videnie Murzy" ("Murza's vision"), "Bog” ("God”), "Na smert' grafini Rumjantsevoj” ("On the death of Countess Rumjantseva"), "Osen' vo vremja osady Ochakova" ("Autumn during the siege of Ochakov"), "Izobrazhenie Felitsy" ("The image of Felice"), "Na kovarstvo frantsuzskogo vozmushchenija" ("On the perfidy of the French rebellion"), and "Na vzjatie Izmaila" ("On the capture of Ismail”).
} 
relatively long word with a stress on the first or second syllable (Gasparov 1984 [1982]). We would not find such homogeneity in Derzhavin and his contemporaries. In their prose and poetry, the average inter-accentual interval in a phrase with the initial adjective is substantially longer: "...umil'nymi svoimi glazámi..." ['(with) your sweet eyes'] (Karamzin, "Poor Liza”, 1792), "V serébrjạnoj.syọèj porfíre" ['in its silver mantle'] (Derzhavin, "Murza's vision”, 1783/1791) and so on. Compare the 19th-century norm: “...svojú pojárkovuju shljápu...” ['his felt hat'] (Tolstoy, "Childhood", 1852), "Svoikh pọchtitel'nykh rabóv" ['their respectful slaves'] (Baratynsky, "Piry" ["The Feasts"], 2nd redaction, 1826) and the like.

All these examples can be explained by several interrelated general tendencies, which can be clearly observed in the material of Russian 19th-century prose fiction.

As early as 1920s Boris Tomashevsky revealed that "accents in the beginning of a sentence are placed more densely than in other parts" (Tomashevsky 1929: 293). Later it was revealed that word-length increases from the beginning of the sentence toward its end (Liapin, Liapina 2004). We cite the summarized data here (from ibid.: 21-22), without any of the unnecessary details. All figures quoted below characterize the change in the length of phonetic words from the beginning to the end of the sentence. Namely, they express the ratio of the frequency of a word of a particular length in the initial position in a sentence to its frequency in the final position in a sentence. Frequencies for the words of this length stressed on the first, second etc. syllable are given in parentheses:

monosyllabic words -4.46 ,

disyllabic words - $1.54(1.69,1.36)$,

trisyllabic words $-0.82(0.83,0.76,0.91)$,

tetrasyllabic words $-0.54(0.70,0.18,1.05,0.52)$,

pentasyllabic words $-0.34(0,0.29,0.31,0.42,1.00)$,

words with six or more syllables -0.26 .

The tendency to an increase in the length of the syllabic interval between the accents can easily be observed not only in a sentence, but also in a colon. We provide the statistics for Tolstoy's prose using Vladislav Kholshevnikov's rhythmic markup of a passage from Chapter II of Tolstoy's "Otrochestvo" ("Adolescence", 1854; see Kholshevnikov 1996: 3-4): the average length of the interval between the first and second accented syllable in a colon is 1.9 syllables; between the second and the third - 2.1 syllables; at the border between the cola - 2.3 syllables. An example: "Vsjá o kréstno st' vdrúg izmenjáe $o_{1} t s j a_{2} \mid$ $i_{3}$ pri $_{4} n i_{5}$ máe ${ }_{1}$ mráchny $j$ kha $a_{2}$ rákte $r$. I| Vót $z a_{1} d_{2} o_{2} z h a ́ l a_{1} o_{2}$ sínovaja róshcha; \|l líst’ja sta $_{2}$ nóvja tsja $_{2}$ ka kógo-to bélo-mútnogo tsvéta..." 
These data complement the observations and conclusions of Tomashevsky, who claimed that "the first interval of a colon tends to shorten, [...] the last interval, on the contrary, increases quite sharply". Moreover, "the law of the lengthening of the last inter-accentual interval finds its correspondence in verse lines": "binary metres primarily accept a pyrrhic on the penultimate foot [...], and it increases the standard [inter-accentual] interval from 1 syllable to 3 syllables" (Tomashevsky 1929: 299-300, cf. 1927: 103-104).

We will hardly need more evidence testifying to the fact that Form III of the iambic tetrameter $\left(\cup \mathcal{L} \cup-\cup \mathcal{L}^{\prime} \dot{L}^{\prime}(\cup)\right)$ is poorly compatible with the Russian phonetic speech norm of the 19th century. ${ }^{13}$ Or, more precisely, if the verse line reveals a tendency to syntactic coherence, the speech structure itself hinders an excessive use of this accentual design. A significant proportion of deviations from the general norm comprises all sorts of amphibology (as in an excerpt from Derzhavin quoted above), the use of outdated syntactic clichés and so on. Also, an inverted word order is quite often used so as to enhance the expressiveness of poetic speech (see examples below).

At the same time, in the first decades of the 19th century there was an increase in the popularity of Form III for a different reason. This was the time when the structural emancipation of syntax from verse began. Enjambment and, more broadly, an imbalance between syntactic and poetic segmentation of speech, as it were, equalized Form III in rights with other frequent rhythmic forms of the Russian iambic tetrameter (I, II, IV, and VI). Consider Pushkin's "Stsena iz Fausta” (“A Scene from Faust", 1825):

Mefistofel'

[...]

I vsékh vas grób, zevạja, zhdét.

Zevạj i tý.

Faust

Sukhája shútka!

Najdí mne spósob kák-nibúdd'

Rasséjat'sjạ.

\footnotetext{
13 We may suppose that this statistical norm started to establish itself no later than the last decade of the 18th century. It is clear that the study of the whole complex of problems mentioned above should be continued.
} 
Mefistofel'

\section{Dovólen búd'}

(III)

Ty dokkazátel'stvom rassúddka.

[...]

Kogó izvólish' pominát',

Ne Grétkhen lị?

Faust

O són chudésnyj!

(III)

O plámja chístoe ljubví! ${ }^{14}$

In this excerpt, in both cases the line with Form III begins with a tetrasyllabic proparoxyton - a phonetic word consisting of four syllables, whose second (antepenultimate) syllable is stressed (Rasséjat'sja; Ne Grétkhen li). Such a word is most frequent at the end of a sentence $-12.3 \%$ of the time, whereas at the beginning of a sentence it is five time less frequent $-2.3 \%$ of the time (Liapin, Liapina 2004: 27-28).

In the Pushkin quotation above, the third-form lines (marked in bold script) are split into two parts by the border between cola, which coincides with the border between the utterances of the interlocutors. "Dovólen búd'..." at the end of the first of these lines is also part of a particular type of enjambment - a contre-rejet (italicized), just as in Pushkin's "Zimnee utro" ("Winter morning", 1829):

Skol'zjạ po útrennemu snégu,

Drúg mílyj, prédadímsja bégu

Neterpelívogo konjá $[. .$.

In stanza XV of the eighth chapter (1829-1830) of Pushkin's Evgenij Onegin, Form III (bold) is produced by another type of enjambment - a rejet (italicized):

14 Cf. James E. Falen's translation: “(Mернisto) [...] All those the yawning grave awaits. / You, too, must yawn. (FAust) An arid jest! / But can you not at least provide / Distraction then? (Mернisto) Be satisfied / With reason's proof [...] Just who it is you treasure so, / Not Gretchen, pray? (FAUST) O wondrous dream! / O purest, brightest flame of love!" (Pushkin 2007: 95-96). 
Niktó b ne móg ejọ prekrásnoj

Nazvát'; no s golový do nóg

Niktó by v néj najtí ne móg

Togó, chto módoj sạmovlástnoj [... $]^{15}$

Compare a rejet and a contre-rejet in stanza XLVII of the same chapter (they are also marked in italics):

A schást'je býlo tạk vozmózhno,

Tàk blízko!.. № sud'bá mojà

Uzh reshená. Neostorózhno,

Byt' mózhet, postupíla jà .

$(\text { III })^{16}$

In all the examples quoted above, the third-form lines begin with a short colon (in some of them this is due to enjambments).

An increase in the proportion of Form III should be noted in the lyric verse of Baratynsky and Nikolai Yazykov (1830s-1840s). ${ }^{17}$ Consider an example from Yazykov’s “Zemletrjasen’je” (“Earthquake”, 1844), where a rejet and a contre-rejet meet at the middle of a third-form line:

Vsevýshnij grádu Konstantịna

Zemlêtrjasén'je posylál,

I gellespóntskaja puchína,

I béreg s grúdoj gór i skál

Drozháli, - i tsaréj paláty,

I khrám, i tsírk, i gịppodróm,

I stẹn gradskíkh verkhí zubcháty,

I vsjó pomórie krugóm.

15 Cf. Nabokov's translation: "None could a beauty / have called her; but from head to foot / none could have found in her / what by the autocratic fashion [/ in the high London circle / is called 'vulgar']" (Pushkin 1981: 288).

16 Cf. Nabokov's translation: "Yet happiness had been so possible, / so near!... But my fate / already is decided. Rashly, / perhaps, I acted" (Pushkin 1981: 307).

17 According to Taranovsky, the proportion of Form III in Yazykov's poems of 1829-1831 is $1.2 \%$. The scholar did not examine Yazykov's later lyric poems. According to the figures provided by Aleksei Beglov (1997), in Yazykov's poems of 1832-1845 the proportion of Form III increased to $1.7 \%$. Taranovsky gives the proportion of Form III in Baratynsky: $0.9 \%$ in $1821-1828$ and $1.6 \%$ in $1829-1843$. 
An even more interesting example is Baratynsky's epigram "Uvy! Tvorets nepervykh sil!” (“Alas! An exhausted creator...", 1835-1841):

\author{
Neápol' vozmutíl rybạár', \\ I, vlást' prijạ́v, kak múdryj tsárar', \\ Dvenádtsat' dnéj on grádom právil; \\ I chtó zhe? - neprivỹchnyj úm, \\ Ustáv ot ventsenósnykh dúm, \\ Egọ $\mathrm{v}$ trinạ́dtsatýj ostávil.
}

The word order in the first line ['The fisherman perturbed Naples'] is important: Neápol' vozmutíl rybár' \{object + verb + subject\}. Compare other possible word orders here: * rybár' vozmutíl Neápol' \{subject + verb + object\}, 'rybár' Neápol' vozmutíl \{subject + object + verb\} etc. The adverbial participle phrase in the fifth line is also revealing (cf. Tumansky's "Ptichka"). In general, any type of grammatical isolation in poetic speech easily upsets the balance of verse segmentation and syntactic segmentation. ${ }^{18}$

A similar construction (a reiteration of Form III resulting from a speech period extended by an adverbial participle phrase) is found in Yakov Polonsky's "I. S. Turgenevu" (“To I[van] S[ergeevich] Turgenev", 1877), see lines 4 and 5:

\section{Kak blédno-ozarénnyj rój}

Besóv, nad snézhnoj pelenój

Nesjótsja v'júga; - kochenéet,

Terjạjas'v neprogljạdnoj mglé,

Bluzhdạ́jushchij obọ́z... Chernéet,

Kak prízrak, v níshchenskom selé

Pustája tsérkov' [.... ${ }^{19}$
(III)

Note that the passage begins with a simile. Compare analogous examples in the poetry of Afanasy Fet:

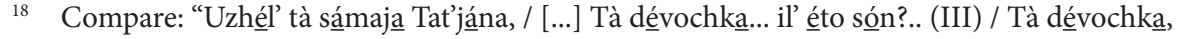
kotóroj ôn (III) / Prenebregál v smirénnoj dóle [...]”. Nabokov’s translation: "Can it be that the same Tatiana / [...] that little girl - or is he dreaming? - / that little girl whom he / had in her humble lot disdained [...]" (Pushkin 1981: 291).

19 'Like a faintly illuminated swarm / of devils over the snowy shroud / drifts the blizzard; stiffens, / disappearing in the impenetrable gloom, / a wandering wagon-train... Blackens, / like a ghost, in the beggarly village / an empty church'.
} 
V dolíne inogdá, proshchájas',

(III)

Krutój minúvvshi povvorót,

Naprásno stránnik, oziráas',

Drugógo gólosọm zovjót.

\section{No smérklos', - nạd stenóju chjórnoj \\ Gorjạ́t izvívy oblakóov, - \\ I tám, vnizúu, s tropý nagórnoj \\ Emú proshchál'nyj slýshen zóv.}

Khochú nestíis' k tebée, letét',

Kak vólny poo ravníne vódnoj,

Potselovát' granít kholódnyj,

Potsellovát' - i unmeréet'!

$(1862)$

The first example features the adverbial participle proshchájas' ['saying goodbye'] followed by the adverbial participle phrase "Krutój minúvshi povorót" ['having passed a sharp turn'] in the first quoted stanza and a contre-rejet in the next stanza (all italicized). The second example features a simile: "Kak vólny po ravníne vódnoj" ['like waves along the water plain'].

The further development of Form III of the iambic tetrameter is closely linked to the general evolution of Russian verse. On the one hand, the quest for aesthetic experimentation would have its influence as well as the fall of various metric, rhythmic, linguistic (etc.) taboos and constraints. On the other hand, poetic speech would drift toward prose fiction and a natural speech norm. Both of these trends would come into complex dialogical relationship. The following are two eloquent examples from 20th-century poetry.

Consider two stanzas from Marina Tsvetaeva's “Toska po rodine! Davno...” (“Homesickness! A long ago..., 1934):

Ne obol'shchúus' i jạzykóm

Rodným, egó prizývom mléchnym.

Mnè bezzrazlíchno - na kakóm

Neponimáemoj bỳt' vstréchnym! 
(Chitátelem, gazétnykh tọnn

Glotátelem, doíl'tsem spléten...)

Dvadtsátogo stolét'ja - ón,

A já - do vsjákogo stoléet'ja! ${ }^{20}$
(III)

(III)

Here, as is usual with Tsvetaeva, verse segmentation and syntactic segmentation are unbalanced, producing numerous enjambments. Not less typical are violations of the "natural" word order (such as "gazétnykh tónn / glotátelem" ['of newspaper tons / a swallower'] or "dvadtsátogo stolét'ja - ón" ['to the twentieth century - he <belongs>']), parentheses, ellipses, and so on.

On the contrary, Ivan Elagin's "Naplyv" ("Fade-over", 1979-1982) is characterized by a relaxed rhythm and regular speech articulation (with an illustrative exception in the following example):

My vyezzháli ịz Chikágo.

Nas býlo chétvero v mashíne.

Tòt dén' bỳl dnjóm poslédnim góda.

Shossé belélo, kàkk bumága,

Stojála zímnjaja pogóda,

No snéga né bylo $\mathrm{v}$ pomíne.

My vyezzháli izz Chikágo.

(A mózhet byt', iz Kurenjóvki

My ékhali na khútor Grúshki.

Zabýlsja ránenyj, bednjága.

Za górodom bez ostanóvki

Peregovárivalis' púshki.) ${ }^{21}$

20 'Nor will entice me my native / language, its milky call. / I don't care, in what tongue / I am misunderstood by whomever I meet! // (By a reader, of newspaper tons / a swallower, a squeezer of gossip...) / To the twentieth century - he [belongs], / And I am - prior to any century!'

${ }^{21}$ 'We were leaving from Chicago. / There were four of us in the car. / That day was the last day of the year. / The highway was glowing white as paper, / it was winter weather, / But there was no trace of snow. [...] We were leaving from Chicago. / (Or maybe it was from Kurenjovka / that we were leaving for Glashka's farm. / The wounded soldier lost consciousness, poor fellow. / Outside the town ceaselessly / were talking guns)'. 
In order to trace in detail the above-mentioned processes and trends, extensive differentiated statistics of the Russian iambic tetrameter from Lomonosov's first experiments to the present day is required. ${ }^{22}$ So far, we only have Taranovsky's data (with large gaps) and the observations made by different scholars regarding the Russian verse of particular poets, particular periods, a particular book of poems, etc. All these data may, however, provide a general (although preliminary) idea of the features and evolution of the Russian iambic tetrameter.

Table 1 contains data suitable for such preliminary comparative assessments. As far as Taranovsky's statistics are concerned (the first ten rows in the table), we had to introduce important corrections and regroup them in order to eliminate an error in combining texts of different poets in his celebrated statistical tables (Taranovsky 1953, Appendix: Tables II and III). Thus, Taranovsky includes Mikhail Lermontov (1814-1841), Aleksei Khomyakov (1804-1860) and Stepan Shevyrev (1806-1864) among the "older" generation of 19th-century poets. At the same time, among his group of the "younger" generation of poets we find Evgeny Baratynsky (1800-1844), Nikolai Yazykov (18031846), and Aleksandr Polezhaev (1804-1838). Significantly, Polezhaev's poems amount to more than a third (38\%) of the total number of lines in Taranovsky's section. Taranovsky did not take into account the lyric iambic tetrameter of such first-rate poets as Afanasy Fet (1820-1892), Nikolai Nekrasov (18211878), Yakov Polonsky (1819-1898), Apollon Maikov (1821-1897), Lev Mei (1822-1862), and A. K. Tolstoy (1817-1875) (see Taranovsky 1953: 66-92; 1980 [1971]). Taranovsky's error is predetermined by his classification of poetic texts according to an irrelevant basis of comparison. As we have already said, Taranovsky's classification is based on the ratio of stresses on the first two ictuses in a four-foot-iambic line. The irrelevance of this parameter for such a classification was demonstrated by Taranovsky himself in co-authorship with Aleksandr Prokhorov in their paper on the Russian iambic tetrameter of 1745-1775 (Taranovsky, Prokhorov 1982). Unfortunately, the co-authors did not extend the scope of their material, did not draw a general conclusion, and thus remained within the traditional paradigm.

As far as was possible, we have restructured and rearranged the periodization (see Table 1).

\footnotetext{
22 Mikhail Lomonosov (1711-1765) was the reformer of Russian versification who established the tradition of using accentual-syllabic metres. His "Oda na vziatie Khotina" ("Ode on the Capture of Khotin”, 1739) was the first Russian poem written in iambic tetrameters.
} 


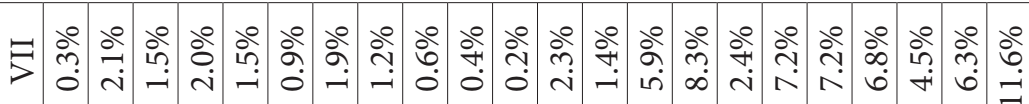

ᄀ

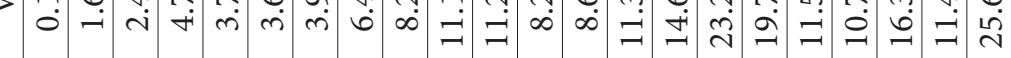

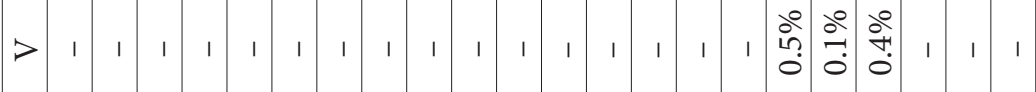

$>$ ¿

Z

\begin{tabular}{|c|c|c|c|c|c|c|c|c|c|c|c|c|c|c|c|c|c|c|c|c|c|}
\hline ヨ & $\begin{array}{l}\partial^{\circ} \\
\sigma^{2}\end{array}$ & $\begin{array}{l}\stackrel{0}{\Lambda} \\
\stackrel{1}{n} \\
\end{array}$ & 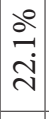 & $\begin{array}{l}\stackrel{0}{\mathrm{~N}} \\
\stackrel{+}{\mathrm{N}}\end{array}$ & $\mid \begin{array}{c}0 \\
+ \\
+1 \\
\infty \\
-1\end{array}$ & $\begin{array}{l}\partial^{0} \\
\stackrel{a}{a}\end{array}$ & 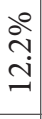 & $\begin{array}{l}\stackrel{0}{a} \\
\beth \\
\beth\end{array}$ & $\begin{array}{l}20 \\
i n ? \\
\end{array}$ & $\mid \begin{array}{l}\partial^{0} \\
0 \\
0\end{array}$ & $\begin{array}{l}\stackrel{\circ}{0} \\
0 \\
\end{array}$ & $\begin{array}{l}\text { 亏े } \\
\text { aे }\end{array}$ & 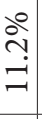 & $\begin{array}{c}0 \\
\text { ño } \\
0 \\
-1\end{array}$ & $\begin{array}{l}\text { 今̊ } \\
10 \\
\end{array}$ & $\begin{array}{l}\stackrel{े}{\mathrm{~N}} \\
\stackrel{+}{+}\end{array}$ & $\begin{array}{l}\stackrel{0}{0} \\
\stackrel{0}{\infty} \\
\infty\end{array}$ & $\begin{array}{l}\stackrel{0}{0} \\
0 \\
\grave{i}\end{array}$ & 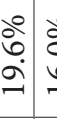 & $\begin{array}{c}0 \\
0 \\
0 \\
0 \\
0 \\
0\end{array}$ & 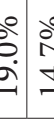 \\
\hline も & 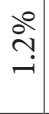 & $\begin{array}{l}\dot{0} \\
\dot{b} \\
\dot{r}\end{array}$ & $\begin{array}{l}\stackrel{0}{0} \\
\dot{b} \\
i\end{array}$ & $\stackrel{\circ}{\stackrel{0}{2}}$ & $\begin{array}{l}\infty \\
\infty \\
\dot{m} \\
\dot{n}\end{array}$ & $\frac{\partial}{\dot{m}}$ & $\begin{array}{l}\stackrel{0}{a} \\
\text { ஸे }\end{array}$ & $\mid \begin{array}{l}\partial \\
\dot{b} \\
+\end{array}$ & $\frac{\partial^{0}}{\sim}$ & $\frac{\partial^{0}}{\sigma^{\circ}}$ & 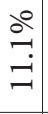 & $\begin{array}{l}\stackrel{0}{ } \\
\infty \\
\end{array}$ & ๙̊’ & $\begin{array}{c}\partial^{0} \\
\stackrel{4}{0} \\
\text { in }\end{array}$ & $\begin{array}{l}\stackrel{0}{ } \\
\overbrace{\infty}\end{array}$ & $\begin{array}{l}\stackrel{0}{2} \\
\text { ஸे }\end{array}$ & 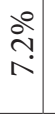 & $\begin{array}{l}\stackrel{0}{0} \\
0 \\
0\end{array}$ & 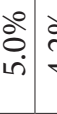 & 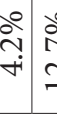 & 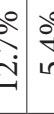 \\
\hline 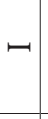 & 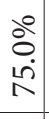 & $\begin{array}{l}\stackrel{\circ}{N} \\
\stackrel{n}{n}\end{array}$ & 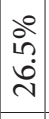 & 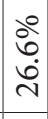 & $\begin{array}{c}\stackrel{0}{\circ} \\
\hat{N} \\
\tilde{m}\end{array}$ & $\begin{array}{l}\stackrel{0}{ } \\
\infty \\
\dot{m} \\
\tilde{m}\end{array}$ & $\begin{array}{l}\circ \\
\infty \\
\dot{n} \\
m\end{array}$ & $\begin{array}{l}\stackrel{2}{人} \\
\stackrel{2}{N} \\
\end{array}$ & $\begin{array}{l}\partial^{0} \\
\stackrel{a}{2}\end{array}$ & 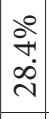 & 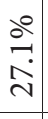 & 吕 & 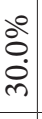 & 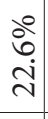 & 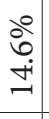 & $\begin{array}{l}\stackrel{0}{ } \\
\infty \\
\stackrel{-}{-}\end{array}$ & $\begin{array}{l}\stackrel{\circ}{\wedge} \\
\stackrel{2}{-}\end{array}$ & $\begin{array}{l}\text { oे } \\
\text { n. } \\
\infty \\
-1\end{array}$ & 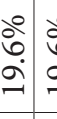 & 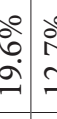 & $\stackrel{2}{c}$ \\
\hline & 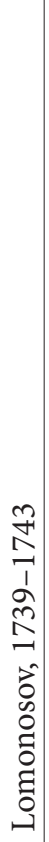 & 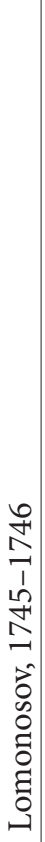 & 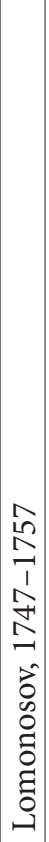 & 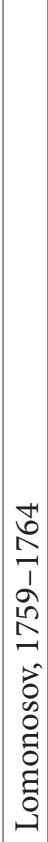 & $\begin{array}{l}8 \\
\infty \\
1 \\
1 \\
1 \\
1 \\
1 \\
1\end{array}$ & 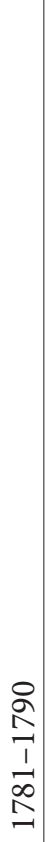 & 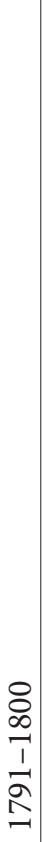 & $\begin{array}{c}0 \\
\infty \\
\infty \\
1 \\
1 \\
0 \\
\infty \\
-1\end{array}$ & 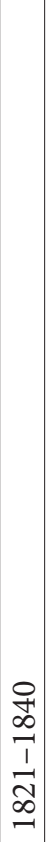 & $\begin{array}{l}\tilde{y} \\
m \\
\infty \\
\infty \\
1 \\
1 \\
\not{1} \\
\infty\end{array}$ & 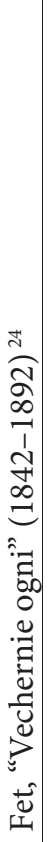 & 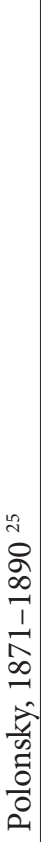 & $\begin{array}{l}2 \\
1 \\
1 \\
\sim \\
\Omega \\
1 \\
\infty \\
\infty \\
\infty \\
\infty \\
=\end{array}$ & 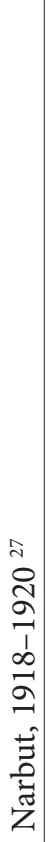 & 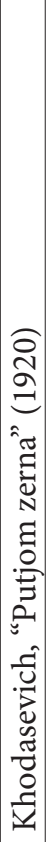 & 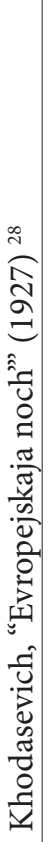 & 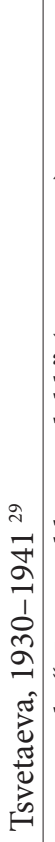 & 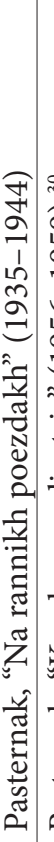 & 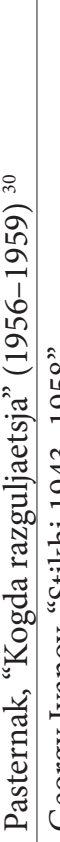 & 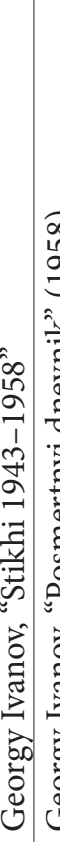 & 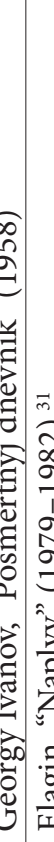 \\
\hline & $-\dot{ }$ & N & $m$ & -7 & & 0 & N & $\infty$ & $a^{\circ}$ & $=$ & $\Xi$ & $\stackrel{\sim}{\sim}$ & $\stackrel{m}{n}$ & $\stackrel{ \pm}{ \pm}$ & 10 & $\stackrel{0}{0}$ & $\triangle$ & $\stackrel{\infty}{-1}$ & $\stackrel{\circ}{二}$ & $\dot{\imath}$ & $\overrightarrow{\mathrm{v}}$ \\
\hline
\end{tabular}


The following charts, built on the basis of this table, illustrate clearly the evolution of the Russian iambic tetrameter from Lomonosov to the mid 20th century. The general trend is unambiguous: after of a period of adaptation, every rhythmic form of the iambic tetrameter approximates as close as possible to the frequency predetermined by the general norms of the Russian literary language. In charts 2-7 below, the figures denoted as "colon" refer to Kholshevnikov's data for fortuitous, quasi-metrical, four-foot-iambic segments in Russian prose (Kholshevnikov 1973), whereas the figures denoted as "st[ochastic] model" refer to Taranovsky's lexical probability model (Taranovsky 1980 [1971]). Even a rapid glance at the charts reveals the absence of any opposition of 18th and 19th century rhythms that resembles what Andrei Belyi and Kiril Taranovsky suggested. ${ }^{32}$

23 Rows 1-10: data from Taranovsky 1953.

24 Data from Shengeli 1923: 152.

25 Our data.

26 Data from Taranovsky 1955/1956: 38.

27 Our data.

28 Rows 15-16: data from Rubtsova 2016: 80.

29 Our data.

30 Rows 18-19: data from Beglov 1997.

31 Rows 20-22: our data.

32 It is quite understandable why the amplitude of oscillations around a particular trend, well discernible in each individual case (toward an increase, a decrease or a stabilization of the average proportion), is wider in the lower part of each chart: material in these parts is more specific, whereas Taranovsky's data are averaged figures for different (and numerous) poets. In three cases, comparability of the data with the other data is questionable: the 1821-1840 period and the 1841-1873 period (see above on the prevalence of the Polezhaev sample and the absence of the majority of the mid-19th-century poets in Taranovsky's statistics), as well as Shengeli's data for Fet's "Vechernie ogni". (Unlike all other scholars, Shengeli's statistics include, in addition to poems with lines of uniform numbers of feet, four-foot-iambic lines from poems with lines of variable lengths.) 


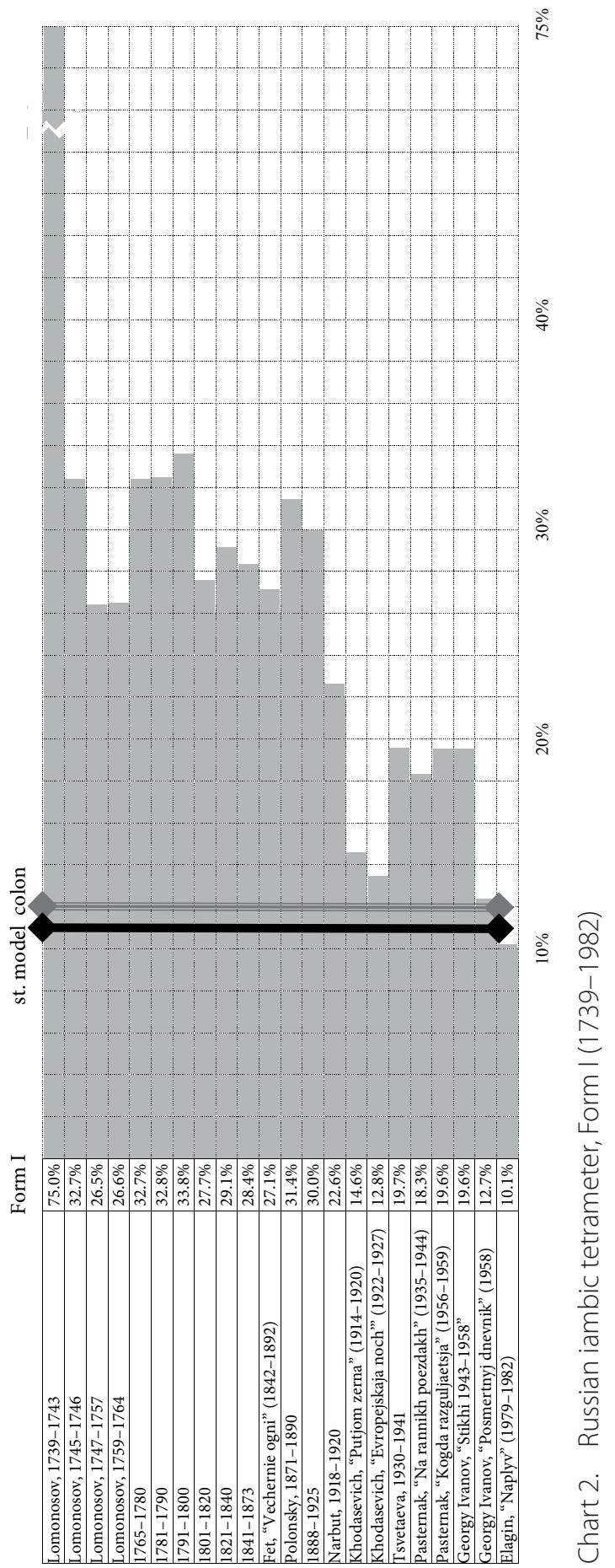


Form II

colon st. model

\begin{tabular}{|l|c|}
\hline Lomonosov, 1739-1743 & $1.2 \%$ \\
\hline Lomonosov, 1745-1746 & $3.6 \%$ \\
\hline Lomonosov, 1747-1757 & $2.6 \%$ \\
\hline Lomonosov, 1759-1764 & $3.2 \%$ \\
\hline $1765-1780$ & $3.8 \%$ \\
\hline $1781-1790$ & $3.1 \%$ \\
\hline $1791-1800$ & $3.9 \%$ \\
\hline $1801-1820$ & $4.6 \%$ \\
\hline $1821-1840$ & $7.1 \%$ \\
\hline $1841-1873$ & $6.1 \%$ \\
\hline Fet, "Vechernie ogni” (1842-1892) & $11.1 \%$ \\
\hline Polonsky, 1871-1890 & $7.8 \%$ \\
\hline $1888-1925$ & $7.9 \%$ \\
\hline Narbut, 1918-1920 & $5.4 \%$ \\
\hline Khodasevich, "Putjom zerna" (1914-1920) & $8.3 \%$ \\
\hline Khodasevich, "Evropejskaja noch”" (1922-1927) & $3.9 \%$ \\
\hline Tsvetaeva, 1930-1941 & $7.2 \%$ \\
\hline Pasternak, "Na rannikh poezdakh" (1935-1944) & $6.0 \%$ \\
\hline Pasternak, “Kogda razguljaetsja” (1956-1959) & $5.0 \%$ \\
\hline Georgy Ivanov, "Stikhi 1943-1958” & $4.2 \%$ \\
\hline Georgy Ivanov, "Posmertnyj dnevnik” (1958) & $12.7 \%$ \\
\hline Elagin, "Naplyv" (1979-1982) & $5.4 \%$ \\
\hline
\end{tabular}

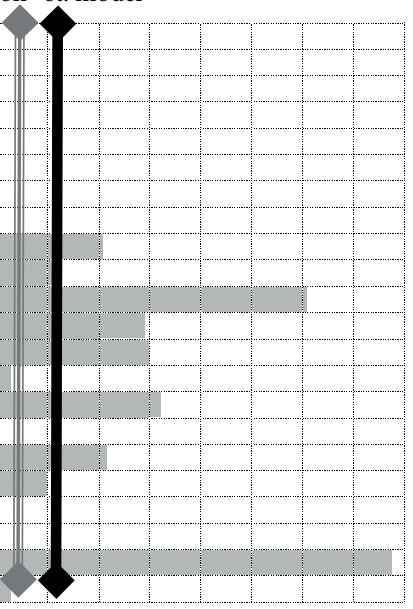

$5 \%$

Chart 3. Russian iambic tetrameter, Form II (1739-1982) 


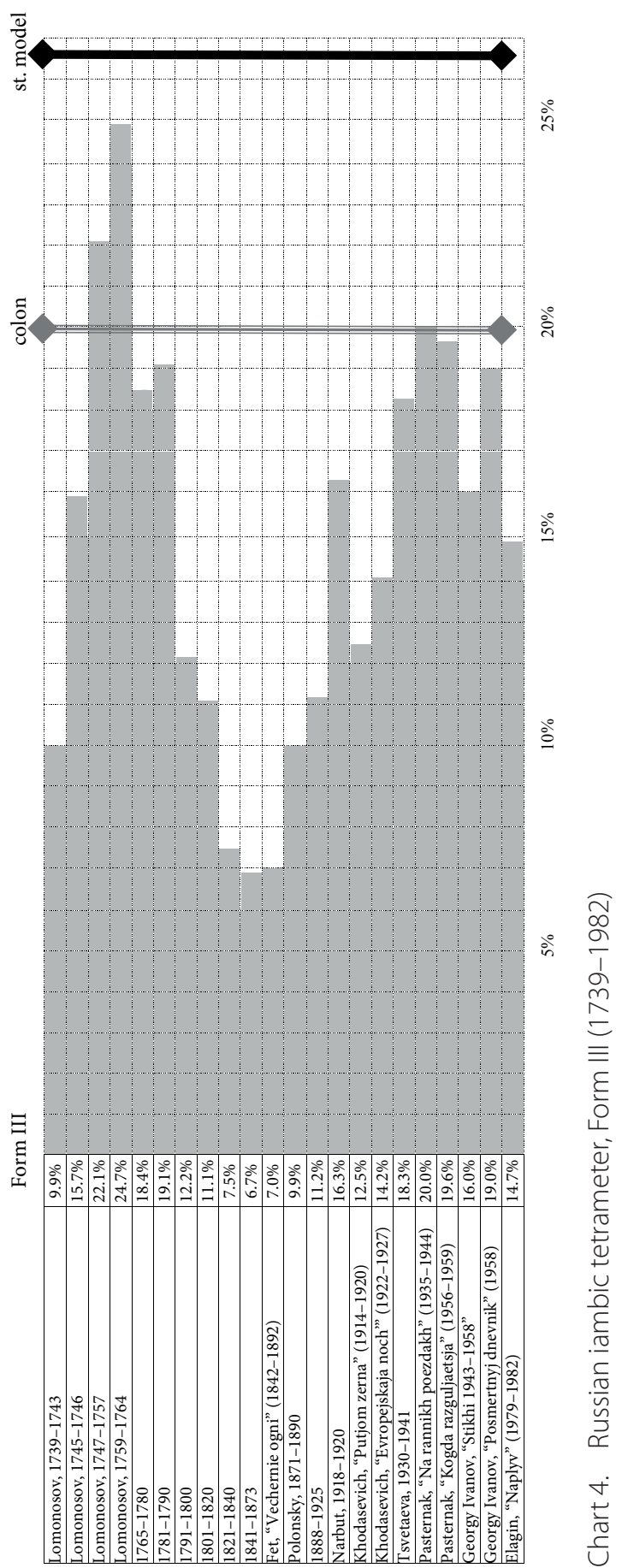




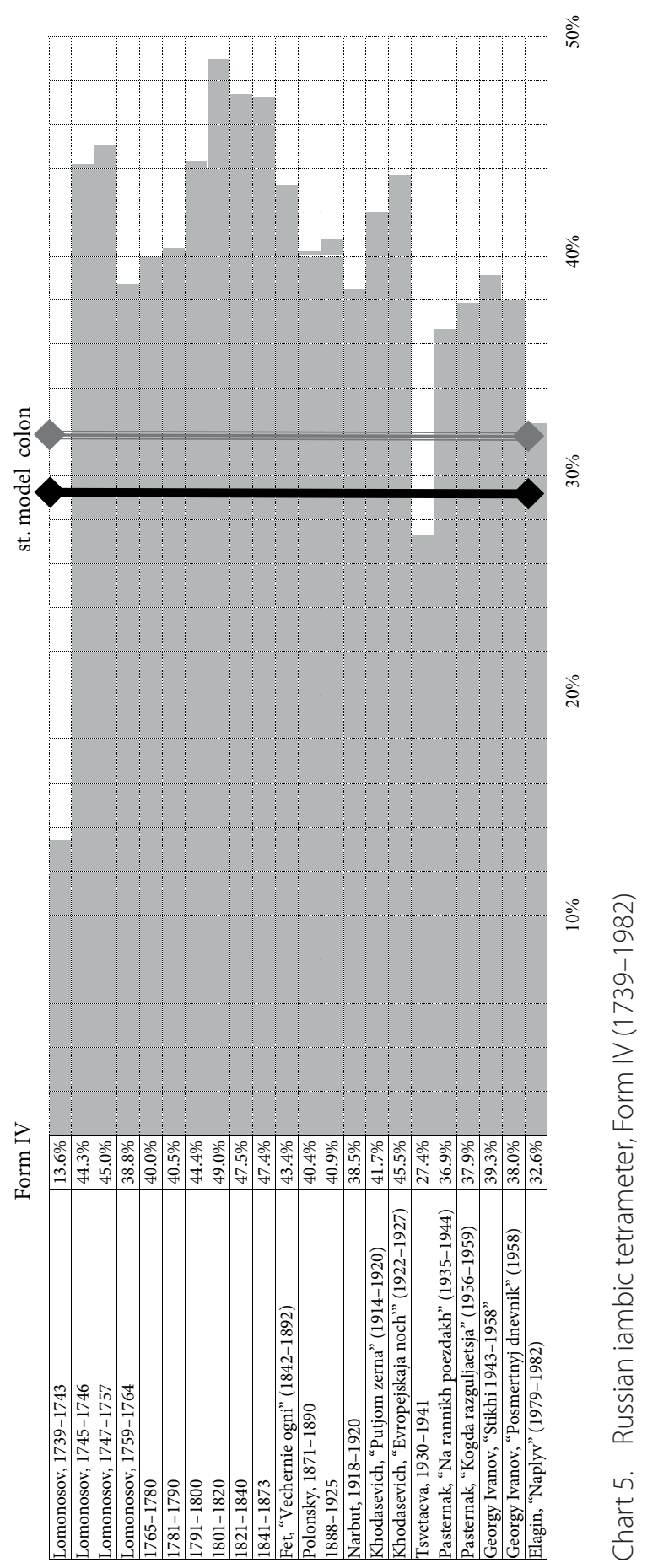




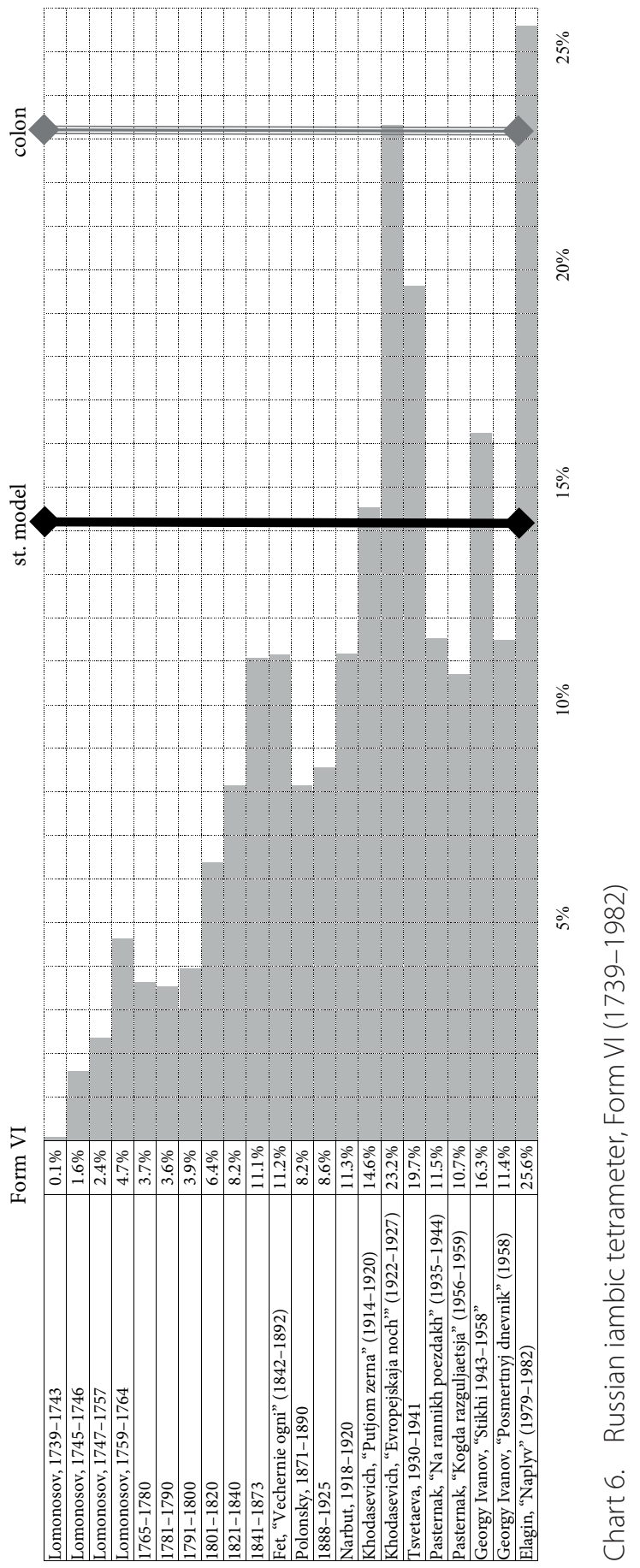




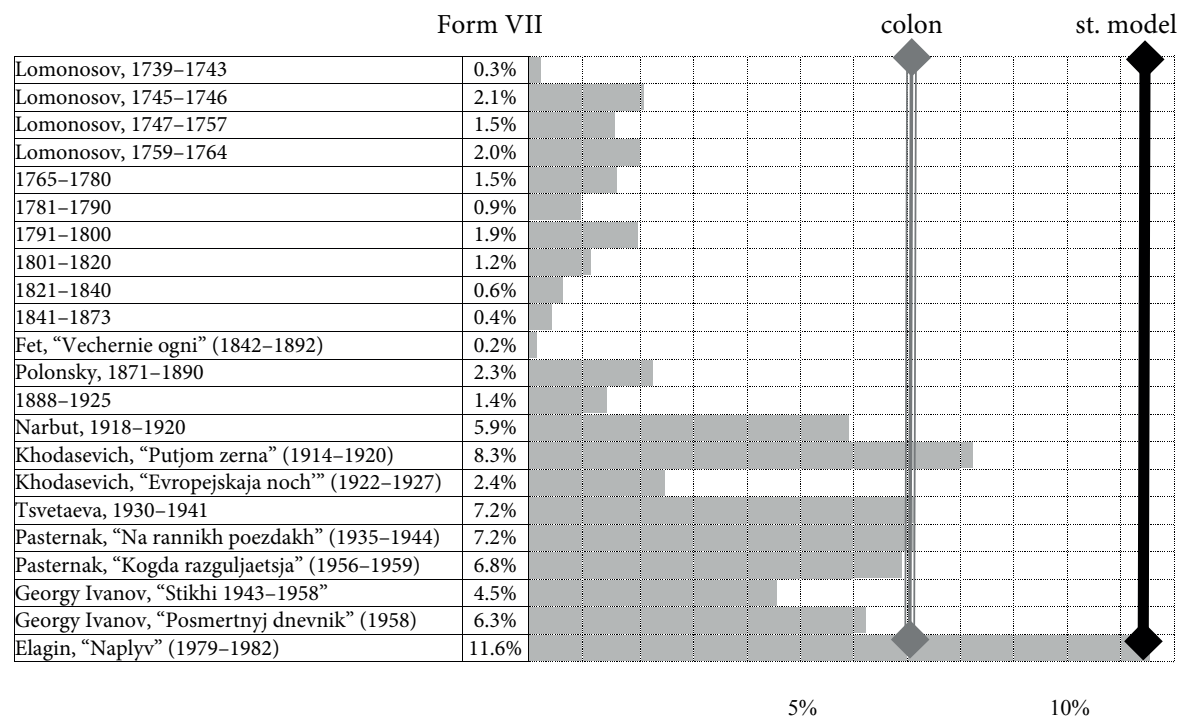

\section{Chart 7. Russian iambic tetrameter, Form VII (1739-1982)}

A short commentary to charts 2-7 will serve as a summary of this article.

An increase in the frequency of Forms II $\left(\cup-\cup^{\prime} \cup^{\prime} \cup^{\prime}-(\cup)\right)$, VI $\left(\cup-\cup{ }^{\prime} \cup-\cup{ }^{\prime}(\cup)\right)$ and VII $\left(\cup \dot{\cup} \cup-\cup-\cup^{\prime}(\cup)\right)$, which initially were rare, is noticed during the whole observation period. This fact indicates the most important, determinative trend line in the development of the Russian iambic tetrameter, namely: its drive for rhythmic diversity. ${ }^{33}$ The limit for an increase in the frequency of these forms proves to be a natural occurrence of such syllabic-accentual structures in speech cola (first and foremost, in prose).

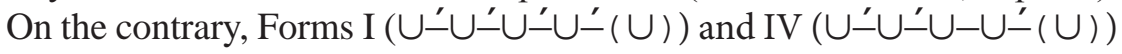
were more frequent in the beginning, but their proportion subsequently decreased. The limit is again determined by a natural speech norm. This is how a common syllabic-accentual balance is eventually set in Russian verse. Some preference given to these forms, however, is noticeable even at the end of the observation period. This may be explained by their structural similarity to the "standard" ("neutral") speech cola. As far as Form I - the fully stressed form - is concerned, its "metricalness" matching the scanned form of the metre may be another factor determining its heightened frequency in the history of the Russian iambic tetrameter, to say nothing of its first steps in the 18th century. An increase in the frequency of Form I is sometimes observed in specific syntactic conditions or in the conditions of elevated emotional

33 This problem was highlighted in a recent article by Andrei Dobritsyn (2016). 
speech (emphasis). Other causes may also be relevant, such as abundance of dialogues, dramatic verse, and so on.

A peculiarity of Form III $(\cup-\cup-\cup \mathcal{L} \cup \dot{-}(\cup)$ ), as we hope to have demonstrated, is its syllabic-accentual structure, which can be described as marginal in terms of Russian speech standards. At the initial stage and in the 20th century it was associated with two different ("lateral") lexical-syntactic niches. The frequency of this form is extremely unstable. During the transitional period, which began in the 1760s-1780s and lasted until 1870, when the new speech norm was being established, a decrease and subsequent increase in the average frequency of Form III is clearly visible. The reason for this "drift" is this specific rhythmic structure's constant pursuit of its lexical and syntactic realization. What we are dealing with here is not a transition to a new type of rhythm, but a local speech trend. This local trend was not governed by any immanent "versological" law. Having exerted a disturbing influence on the average trend line, which describes an increase in the degree of rhythmic diversity of the metre under consideration, this trend could only complicate this process to a certain extent during the transition period. (This is the most important conclusion of this article.)

The last chart (Chart 8) illustrates the mechanism of the formation of "Taranovsky's parameter" as an overlapping of all above-mentioned factors (the oblique arrow indicates the transition period).

The apparent simplicity of the evolution of the consolidated parameter during the transition period disguises a combination of two heterogeneous trends. The first trend is that each rhythmic form (II, III, VI, and VII) tends to increase in frequency, and this growth is constrained only by the language and speech norms. The first trend is an accentual-syllabic form's drive to find stability in the changing reality of speech. The latter tendency is specific for Form III, with its restricted ability to function in the speech process.

In conclusion, let us dwell very briefly upon the characteristics of the other two periods: before and after the period we conditionally refer to as transitional.

The period before the "transition" is, basically, experimental. It comprises Lomonosov's creative quest for a suitable sound of the iambic tetrameter that would prove organic and viable on Russian soil (cf. Shapir 1996a, 1996b). In this early period, various and heterogeneous factors as well as rapid rhythmic and stylistic transformation are condensed in a short temporal interval. As a result, the averaged trend line is close to a purely stochastic motion. However, a careful analysis of all the components of the movement is needed. Then and only then will many essential features of the poetics of Lomonosov's iambic tetrameter be clarified. 


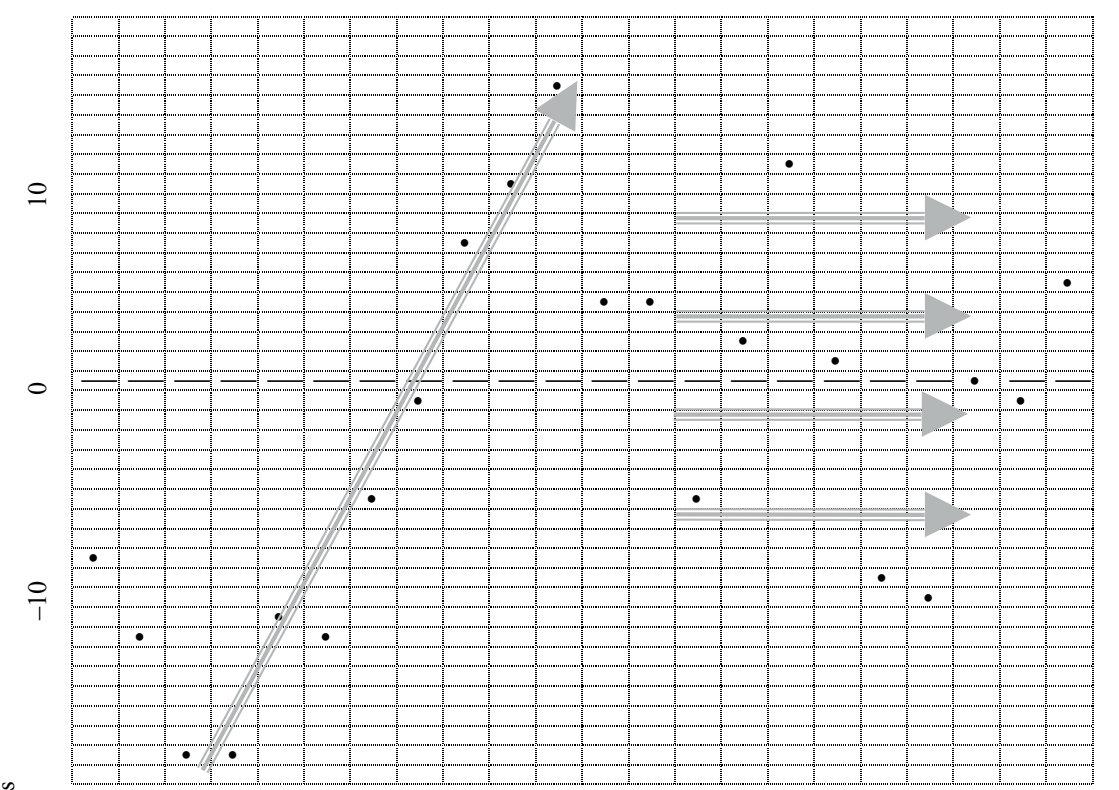

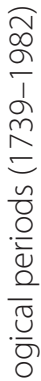

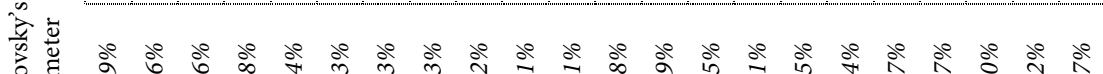

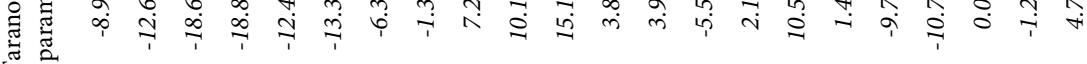

औ

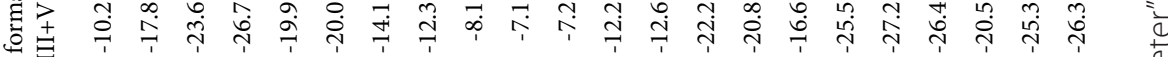

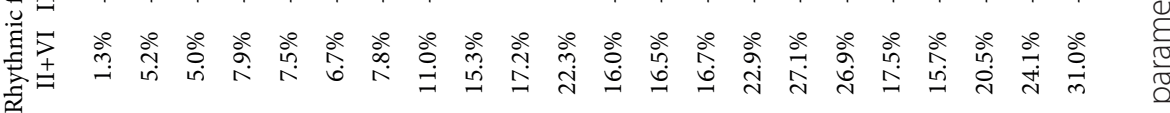

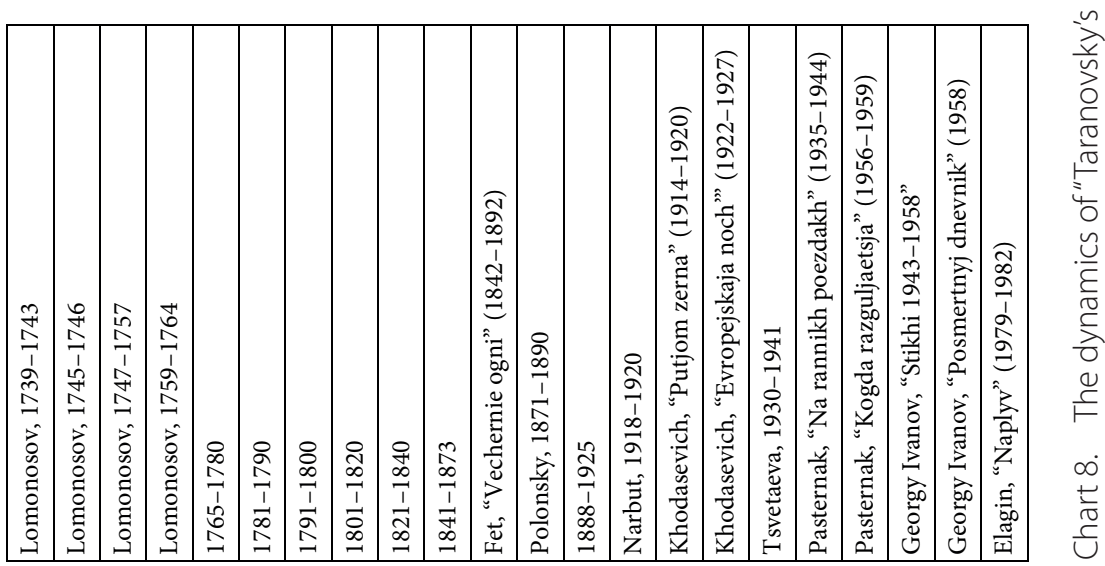


The main characteristic of the latest period in the development of the Russian iambic tetrameter is that the arterial road of verse leading to rhythmic diversity, which could earlier be detected only by means of special analysis, becomes clear and obvious. Form III finally finds its place in the general rhythmic system. The drive toward a total liberation of verse from all kinds of versification bans and constraints at different levels of verse structure is already discernible in the poems of Yakov Polonsky, Aleksandr Blok and other poets of the late 19th and early 20th century. Dispersion of rhythmic characteristics in the works of 20th-century poets, which is clearly visible on all charts, is symptomatic of this trend. One of the priorities of contemporary verse theory is a methodologically well-founded study of the Russian iambic tetrameter of this period. ${ }^{34}$

\section{References}

Beglov, Aleksei L'vovich 1997. Monotonija poeticheskoj rechi (na materiale russkogo 4-stopnogo jamba XVIII-XX vv.) Diplomnaja rabota studenta V kursa (unpublished BA thesis). Moskovskij gosudarstvennyj universitet imeni M. V. Lomonosova. Filologicheskij fakul'tet.

Belyi, Andrei 1910. Simvolizm: Kniga statej. Moskva: Musaget.

Červenka, Miroslav 1973. Ritmicheskij impul's cheshskogo stikha. In: Jakobson, Roman; Schooneveld, Cornelis H. van; Worth, Dean S. (eds.), Slavic Poetics: Essays in honor of Kiril Taranovsky. The Hague, Paris: Mouton, 79-90.

Dobritsyn, Andrei (2016). Rhythmic entropy as a measure of rhythmic diversity (The example of the Russian iambic tetrameter). In: Studia Metrica et Poetica 3(1), 33-52.

Gasparov, Mikhail Leonovich 1984 [1982]. Ritmicheskij slovar' i ritmikosintaksicheskie klishe. In: Grigor'jev, V. P. (ed.), Problemy strukturnoj lingvistiki 1982. Moskva: Nauka, 169-185.

Gasparov, Mikhail Leonovich 1984. Ocherk istorii russkogo stikha: Metrika. Ritmika. Rifma. Strofika. Moskva: Nauka.

34 My sincerest thanks to Igor Pilshchikov for his creative scholarly editing of this article; no less important for me have been our constant discussions of the problem to which this article is devoted. I am grateful to Andrei Dobritsyn and Larisa Liapina for valuable advice. I am also and particularly grateful to Ivan Eubanks, who found the time to copyedit my text on very short notice. 
Kholshevnikov, Vladislav Evgen'evich 1973. Sluchajnye chetyrekhstopnye jamby v russkoj proze. In: Jakobson, Roman; Schooneveld, Cornelis H. van; Worth, Dean S. (eds.), Slavic Poetics: Essays in honor of Kiril Taranovsky. The Hague, Paris: Mouton, 549-557.

Kholshevnikov, Vladislav Evgen'evich 1981. Zametki o russkom stikhe XVIII veka. In: Makogonenko, G. P.; Panchenko, A. M. (eds.), Problemy istorizma v russkoj literature. Konets XVIII - nachalo XIX v. (XVIII vek 13). Leningrad: Nauka, 229-243.

Kholshevnikov, Vladislav Evgen'evich 1996. Osnovy stikhovedenija: Russkoe stikhoslozhenie. Izdanie 3-e, pererabotannoe. Sankt-Peterburg: Izdatel'stvo SanktPeterburgskogo universiteta.

Levashov, Aleksandr Mikhailovich 2015. Pochemu ne sushchestvuet zakona regressivnoj aktsentnoj dissimiljatsii. Paper presented at the Gasparov Readings 2015 [Gasparovskie chtenija-2015] held at the Russian State University for the Humanities (RGGU, Moscow, 16-18 April 2015).

Liapin, Sergei Evgen'evich 1997a. K demifologizatsii ritmiki russkogo 4-stopnogo jamba (preimushchestvenno na materiale odicheskogo stikha Derzhavina). In: Philologica 4(8/10), 307-322.

Liapin, Sergei Evgen'evich 1997b. Demythologizing the rhythm of the Russian iambic tetrameter (primarily on the basis of Deržavin's odic verse). In: Philologica 4(8/10), 323-324. [A synopsis of Liapin 1997a.]

Liapin, Sergei Evgen’evich 2011. "Segmentnyj” dol'nik: K opisaniju metricheskikh novatsij Iosifa Brodskogo. In: Vestnik Moskovskogo universiteta. Serija 9: Filologija $6,36-46$.

Liapin, Sergei Evgen'evich 2015. O nesostojatel'nosti “avtonomnykh stikhovykh zakonov". Paper presented at the Gasparov Readings 2015 [Gasparovskie chtenija-2015] held at the Russian State University for the Humanities (RGGU, Moscow, 16-18 April 2015).

Liapin, Sergei Evgen'evich; Liapina, Maria Sergeevna 2004. Aktsentnoe stroenie russkoj rechi: slovo - predlozhenie - stikh. In: Gasparov, M. L.; Skulacheva, T. V. (eds.), Slavjanskij stikh VII: Lingvistika i struktura stikha, Moskva: Jazyki slavjanskoj kul'tury, 11-28.

Liapin, Sergei Evgen'evich; Florinskaja [Liapina], Maria Sergeevna (forthcoming). Russkij 4-stopnyj khorej: ritm - jazyk - problema tipologii. In: Levashov, A. M.; Prokhorov, A. V.; Skulacheva, T. V. (eds.), Slavjanskij stikh X. Moskva: Institut russkogo jazyka imeni V. V. Vinogradova RAN. 
Liapin, Sergei [Ljapin, Sergej]; Pilshchikov [Pilščikov], Igor 2012. Nad prvním ruským výborem prací Miroslava Červenky. Tr. A. Machoninová, In: Česká literatura 60(3), 428-444.

Pushkin, Aleksandr [Sergeevich] 1981. Eugene Onegin: A Novel in Verse, Translated from the Russian, with a Commentary, by Vladimir Nabokov. [A revised edition]. Paperback edition in two volumes. Vol. 1. Princeton: Princeton University Press.

Pushkin, Aleksandr [Sergeevich] 2007. Boris Godunov and Other Dramatic Works. Translated with Notes by James E. Falen. With an Introduction by Caryl Emerson. New York: Oxford University Press.

Petrova, Anna Aleksandrovna 2010. Ritmicheskij stroj severnoj chastushki. In: Otechestvennoe stikhovedenie: 100-letnie itogi i perspektivy razvitija: Materialy Mezhdunarodnoj nauchnoj konferentsii 25-27 nojabrja 2010 g. Sankt-Peterburg. Ed. by Bogdanov, S. I.; Khvorost'janova, E. V. Sankt-Peterburg: Filologicheskij fakul'tet SPbGU, 198-204.+

Polilova, Vera Sergeevna; Levashov, Aleksandr Mikhailovich 2016. Gasparovskie chtenija-2015 (RGGU, 16-18 aprelja 2015 g.): 1. Stikhovedenie. In: Novoe literaturnoe obozrenie 137, 382-388.

Rubtsova, Anna 2016. Stikhoslozhenie Vladislava Khodasevicha (Tallinn University Dissertations on Humanities 30). Tallinn: Tallinn University Press (pdf).

Shapir, Maksim Il'ich 1996a. U istokov russkogo chetyrekhstopnogo jamba: genezis i evoljutsija ritma (K sotsiolingvisticheskoj kharakteristike stikha rannego Lomonosova). In: Philologica 3(5/7), 69-101.

Shapir, Maksim Il'ich 1996b. At the dawn of the Russian iambic tetrameter: the genesis and evolution of rhythm (On the sociolinguistic characteristics of Lomonosov's early versification). In: Philologica 3(5/7), 102-108. [A synopsis of Shapir 1996a.]

Shengeli, Georgy Arkadievich 1923. Traktat o russkom stikhe. Chast' 1: Organicheskaja metrika. Izdanie 2-e, pererabotannoe. Moskva, Petrograd: Gosudarstvennoe izdatel'stvo.

Taranovsky, Kiril 1953. Ruski dvodelni ritmovi I-II. Beograd: Naučna knjiga.

Taranovsky, Kiril 1955/1956. Ruski četvorostopni jamb u prvim dvema decenijama XX veka. In: Južnoslovenski filolog 21(1/4), 15-43.

Taranovsky, Kiril [Kirill Fedorovich] 1966. Osnovnye zadachi statisticheskogo izuchenija slavjanskogo stikha. In: Poetics. Poetyka. Poetika II, The Hague, Paris: Mouton; Warszawa: PWN [Państwowe Wydawnictwo Naukowe] = Polish Scientfic Publishers, 173-196. 
Taranovsky, Kiril [Kirill Fedorovich] 1971. O ritmicheskoj strukture russkikh dvuslozhnykh razmerov. In: Alekseev, Mikhail Pavlovich (ed.), Poetika i stilistika russkoj literatury: Pamjati akademika Viktora Vladimirovicha Vinogradova. Leningrad: Nauka, 420-429.

Taranovsky, Kiril [Kirill Fedorovich] 1980 [1971]. The rhythmical structure of Russian binary metres. Translated by Gerald Stanton Smith. In: Russian Poetics in Translation 7, 20-30. [A translation of Taranovsky 1971.]

Taranovsky, Kiril [Kirill Fedorovich]; Prokhorov, Aleksandr Vladimirovich 1982. K kharakteristike russkogo chetyrekhstopnogo jamba XVIII veka: Lomonosov, Trediakovskij, Sumarokov. In: Russian Literature 12(2), 145-194.

Tomashevsky, Boris Viktorovich 1927. Teorija literatury. Poetika. 2-e, ispravlennoe izdanie. Moskva, Leningrad: Gosudarstvennoe izdatel'stvo.

Tomashevsky, Boris Viktorovich 1929. Ritm prozy ("Pikovaja dama"). In his O stikhe. Leningrad: Priboj, 254-318. 